\title{
Sistem Pakar Deteksi Apendisicitis
}

\author{
Firna Yenila ${ }^{1}$, Yogi Wiyandra ${ }^{2}$ \\ ${ }^{1,2}$ Universitas Putra Indonesia YPTK Padang,Indonesia \\ firnayenila@upiyptk.ac.id, yogiwiyandra@upiyptk.ac.id
}

\begin{abstract}
Abstrak
Penyakit radang usus buntu (Apendisicitis) terdapat di seluruh dunia dan dapat menyerang semua orang, baik pria maupun wanita. Jika radang usus buntu tidak dapat dikenali atau diobati, usus buntu bisa pecah, membuat kantung meradang di luar usus tersebut dan menimbulkan nanah.Akibat lanjut, benda dari usus buntu masuk ke rongga perut, menyebabkan peradangan serius.Untuk mengetahuinya Penyakit Radang Usus Buntu mereka harus mengunjungi dokter.Dengan kondisi demikian dirancanglah sebuah sistem yang mampu memberikan solusi terhadap pasien atau user yang mengalami kondisi tersebut.Sistem yang dibangun merupakan sistem pakar dengan melibatkan dokter yang ahli dibidangnya sebagai pakar dan menyadurkan informasi melalui pakar dan diterapkan kedalam sebuah sistem.Sistem pakar ini menggunakan metode backward chaining dalam pembacaan datanya ketika user atau pasien konsultasi.Sistem ini berbasiskan website dan bisa digunakan di berbagai smartphone, hasil dari sistem ini juga bisa digunakan dalam bentuk hardcopy.
\end{abstract}

Kata kunci:Sistem Pakar, Backward Chaining, Apendisicitis

\begin{abstract}
Appendicicitis is found throughout the world and can affect everyone, both men and women. If inflammation of appendicitis cannot be recognized or treated, appendicitis can rupture, make an inflamed sac outside the intestine and cause pus. As a result, objects from the appendix enter the abdominal cavity, causing serious inflammation. To find out appendicitis they must visit a doctor. With this condition a system is designed that is able to provide solutions to patients or users who experience these conditions. It is built an expert system involving doctors who are experts in their field as experts and adapt information through experts and applied to a system. using the backward chaining method in reading the data when the user or patient is consulting. It is based on a website and can be used on various smartphones, the results of this system can also be used in hardcopy.
\end{abstract}

Kata kunci:Expert System, Backward Chaining, Apendisicitis

\section{Pendahuluan}

Penyakit radang usus buntu (Apendisicitis) terdapat di seluruh dunia dan dapat menyerang semua orang, baik pria maupun wanita. Penyakit radang usus buntu disebabkan oleh bakteri dan makan cabai bersama bijinya atau jambu klutuk beserta bijinya sering kali tidak tercerna dalam tinja dan menyelinap kesaluran appendiks sebagai benda asing. gejala radang usus buntu umumnya mengalami sakit perut, terutama dimulai di sekitar pusar dan bergerak kesamping kanan bawah, penurunan nafsu makan, mual dan muntah, serta diare(Arifuddin, Salmawati, and Prasetyo 2017).

Seseorang yang mengalami penyakit cacing (cacingan), apabila cacing yang beternak didalam usus besar lalu tersasar memasuki usus buntu maka dapat menimbulkan penyakit radang usus buntu.Peradangan atau pembengkakaan yang terjadi pada usus buntu menyebabkan aliran cairan limfe dan darah tidak sempurna pada usus buntu (appendiks) akibat adanya tekanan, akhirnya usus buntu mengalami makanan lagi.

$\begin{array}{ll}\text { Dikirim } & : \text { 2019-03-22 } \\ \text { Diterima } & : 2019-04-08 \\ \text { Diterbitkan } & : \text { 2019-04-08 } \\ \text { DOI } & : \text { https://doi.org/10.29165/komtekinfo.v5i2 }\end{array}$


Sistem pakar adalah sebuah sistem yang mengadopsi pengetahuan manusia ke dalam komputer agar komputer dapat menyelesaikan masalah seperti seorang pakar. Sistem pakar banyak diterapkan dalam berbagai bidang salah satunya dalam bidang kesehatan. Berdasarkan hal tersebut maka dibutuhkan sebuah sistem pakar yang bisa di akses kapanpun dan dimanapun sebagai alternatif penyajian informasi dan konsultasi yang lebih ekonomis, karena melihat jumlah penderita Apendisitis yang lumayan banyak dikalangan masyarakat. Sistem pakar ini akan menggunakan teknik Backward chaining, yaitu teknik pencarian yang dimulai dengan hipotesa yang, kemudian mencocokkan dengan fakta yang ada.dalam hal ini gejalah penyakit digunakan sebagai fakta, setelah semua data gejalah terpenuhi dapat digunkan untuk menarik kesimpulan mengenai suatu penyakit.

\section{Tinjauan Literatur}

\subsection{Sistem Pakar}

Sistem pakar (expert system) adalah sistem yang berbasis komputer yang menggunakan pengetahuan, fakta, dan teknik penalaran dalam memecahkan masalah yang biasanya hanya dapat dipecahkan oleh seorang pakar. Bagi para ahli sistem pakar juga membantu aktivitasnya sebagai asisten yang sangat berpengalaman.Sistem pakar juga dapat memberikan penganalisaan terhadap masalah dan juga dapat merekomendasikan pada penguna beberapa tindakan untuk melakukan perbaikan (Firna Yenila 2016).

\subsection{Memory Kerja}

Memori kerja yang digunakan untuk menyimpan fakta-fakta yang diperoleh saat dilakukan proses konsultasi. Konklusinya bisa berupa hasil diagnosa, tindakan, akibat.

\subsection{Fasilitas Penjelas (Explaining Facility)}

Sebagian besar sistem pakar komersial dibuat dalam bentuk rule-based systems, yang mana pengetahuan disimpan dalam bentuk aturan-aturan.Aturan tersebut biasanya berbentuk $I F$ THEN [3]. Seperti gambar struktur sistem pakar berikut:

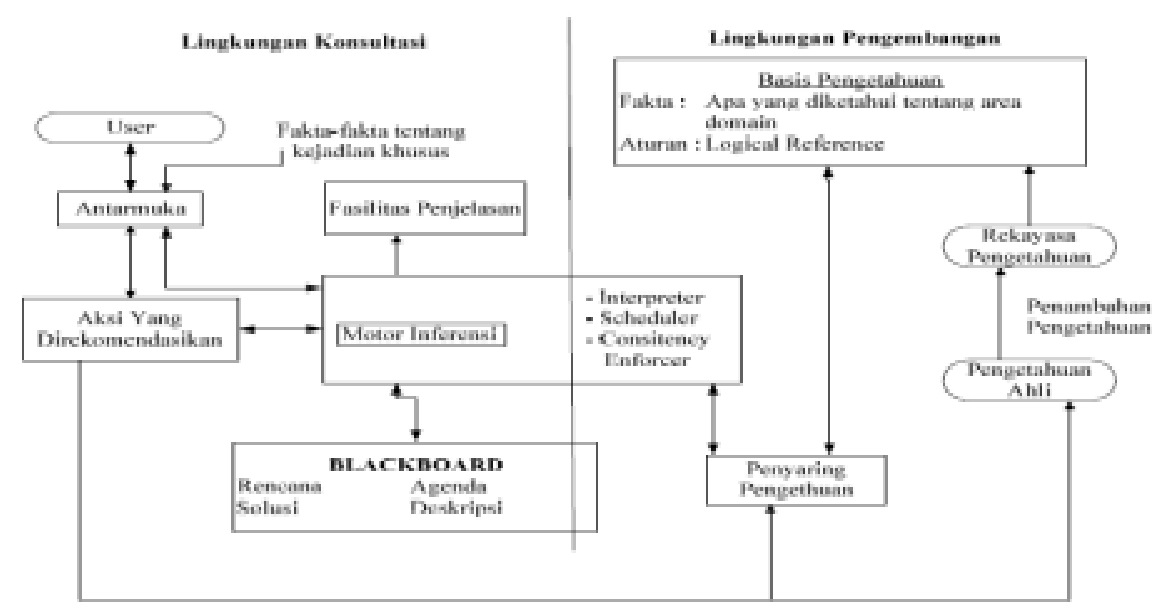

Gambar 1: Struktur Sistem Pakar

\subsection{Motor Inferensi (Inference Engine)}

Motor inferensi mengandung mekanisme pola pikir dan penalaran yang digunakan oleh pakar dalam menyelesaikan suatu masalah dalam Sistem Pakar, yaitu Forward Chaining dan Backward Chaining. 


\begin{tabular}{|l|l|}
\hline No & Aturan \\
\hline R-1 & IF A \& B THEN C \\
\hline R-2 & IF C THEN D \\
\hline R-3 & IF A \& E THEN F \\
\hline R-4 & IF A THEN G \\
\hline R-5 & IF F \& G THEN D \\
\hline R-6 & IF G \& E THEN H \\
\hline R-7 & IF C \& H THEN I \\
\hline R-8 & IF I \& A THEN J \\
\hline R-9 & IF G THEN J \\
\hline R-10 & IF J THEN K \\
\hline &
\end{tabular}

Tabel 1: Contoh Aturan-Aturan

Pada tabel terlihat ada 10 aturan yang simpan dalam basis pengetahuan. Fakta awal yang diberikan hanya: A \& F (artinya: A dan F bernilai benar). Ingin dibuktikan apakah K benilai benar (hipotesis $\mathrm{K})$.Ingin diperoleh konklusi dari daftar konklusi yang ada berdasarkan premis-premis dalam aturan dan fakta yang diberikan oleh user. Berikut ini adalah daftar aturannya :

Aturan 1:

Jika premis 1

Dan premis 2

Dan premis

Maka konklusi 1

Aturan 2:

Jika premis 1

Dan premis 3

Dan premis 4

Maka konklusi 2

\subsection{Metode Pencarian}

Hal penting dalam menentukan keberhasilan sistem berdasar kecerdasan adalah kesuksesan dalam pencarian dan pencocokan, pada dasarnya menurut[4], ada dua teknik pencarian dan pelacakan yang digunakan yaitu pencarian buta (blind search) dan pencarian terbimbing (heuristic search).

a. Pencarian Buta (Blind Search)

Pencarian buta ada beberapa metode yang digunakan adalah :

1. Pencarian melebar pertama (Breadth First Search)

Pencarian dilakukan pada semua simpul dalam setiap level secara berurutan dari kiri ke kanan[4]

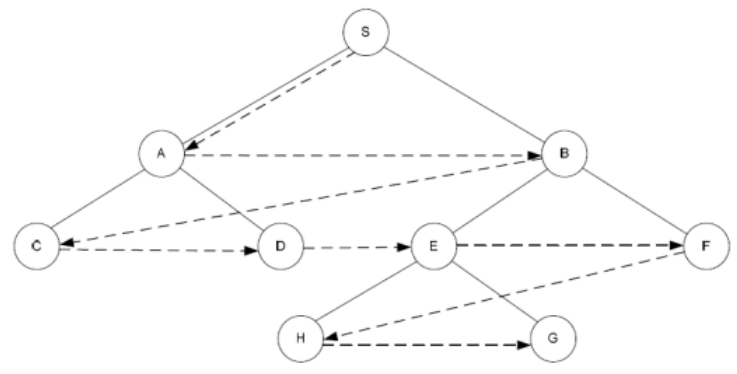

Gambar 2: Breadth First Search 
2. Pencarian Mendalam Pertama (Depth-First Search)

Pada Pencarian depth first search, proses pencarian akan dilakukan pada semua anaknya sebelum dilakukan pencarian ke node-node yang selevel.

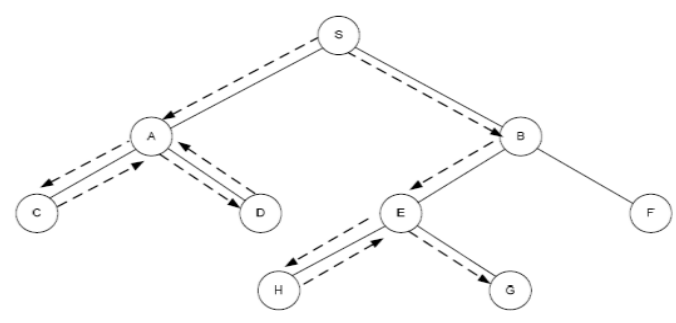

Gambar 3: Depth-First Search

\section{b. Pencarian Heuristik ( Heuristik Search)}

Ada beberapa metode pencarian heuristik :

1. Pembangkitan dan Pengujian (Generate And Test)

2. Pendakian Bukit (Hill Climbing)

3. Pencarian Terbaik Pertama (Best First Search)

\subsection{Teknik Inferensi Forward Chaining Dan Backward Chaining}

\section{a. Forward Chaining}

Forward chaining adalah teknik pencarian yang mulai dengan fakta yang diketahui, kemudian mencocokkan fakta-fakta tersebut dengan bagian IF dari rule IF-THEN, bila ada fakta yang cocok dengan IF, maka rule tersebut dieksekusi. Bila sebuah sebuah rule dieksekusi maka sebuah fakta baru (bagian THEN) ditambahkan kedalam database[5]

\section{b. Backward Chaining}

Backward chaining adalah metode inferensi yang bekerja mundur kearah kondisi awal.proses diawali dari Goal(yang berada dibagian THEN dari rule IF-THEN), kemudian pencarian mulai dijalankan untuk mencocokkan apakah fakta-fakta yang cocok dengan premis-premis dibagian IF[5].

\section{Metodologi}

Metodology penelitian yang dilakukan dalam membuat penelitian ini sesuai dengan framework berikut: 


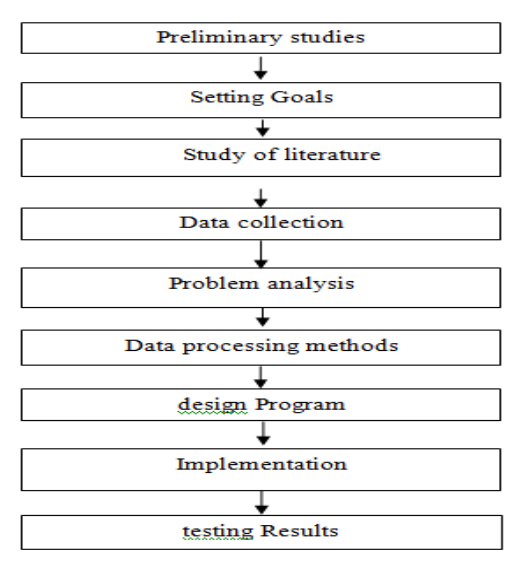

Gambar 4: Metodology Penelitian

\section{Hasil dan Diskusi}

\subsection{Analisa Sistem}

Penderita radang usus buntu pada awalnya tidak mengetahui gejala maupun penyakit yang dideritanya karena kurangnya informasi yang mereka ketahui.Untuk mengetahui kondisi mereka beserta dengan diagnosa awal usus mereka, mereka akan mendatangi dokter untuk berkonsultasi. Akan tetapi, hal tersebut tidak dapat dilakukan oleh semua orang mungkin karena faktor perekonomian yang kurang mencukupi ataupun karena tuntutan kesibukan dan aktifitas mereka yang padat sehingga tidak bisa menyesuaikan dengan jadwal praktek dokter. Terkadang ketika berkonsultasi pun informasi hasil diagnosa yang disampaikan oleh dokter tidak sepenuhnya dipaparkan secara mendetail.

Berdasarkan hal tersebut, maka diperlukan suatu alat bantu yang mampu merepresentasikan keahlian seorang pakar (dokter spesialis) dan dapat diakses dimanapun dan kapanpun.

Jenis radang usus buntu yang didiagnosa menurut pakar adalah sebagai berikut :

1. Radang Usus Buntu Kronis

Radang Usus Buntu Kronik (Apendisitis Kronis) disebabkan oleh tersumbatnya sebagian usus buntu dengan sipat menahun dan kambuhan.

2. Radang Usus Buntu Akut

Radang Usus Buntu Akut (Apendisitis akut) adalah suatu proses penyumbatan yang mengakibatkan mukus yang diproduksi mukosa mengalami bendungan.

\subsection{Representasi Pengetahuan}

Representasi pengetahuan merupakan metode yang digunakan untuk mengkodekan pengetahuan dalam sebuah sistem pakar yang berbasis pengetahuan. Representasian dimaksudkan untuk menangkap sifat-sifat penting masalah dan membuat informasi itu dapat diakses oleh prosedur pemecahan masalah. 


\section{a. Data Penyakit}

Berikut ini adalah daftar jenis-jenis Radang usus buntu yang didiagnosa:

\begin{tabular}{cc} 
KodePenyakit & JenisRadang Usus Buntu \\
\hline P001 & Radang Usus Buntu Kronis \\
\hline P002 & Radang Usus Buntu Akut \\
\hline
\end{tabular}

\section{b. Data Gejala}

Berikut ini adalah daftar gejala radang usus buntu secara umum:

\begin{tabular}{cl}
\hline Kode Gejala & \multicolumn{1}{c}{ Gejala } \\
\hline G001 & Nyeri ulu hati \\
\hline G002 & Mual Dan Muntah \\
\hline G003 & $\begin{array}{l}\text { Nyeri samar dibagian pusar berpindah ke kanan } \\
\text { bawah. }\end{array}$ \\
\hline G004 & Nyeri perut bagian kanan yang hilang timbul \\
\hline G005 & Nyeri perut kanan bawah lebih dari dua minggu \\
\hline G006 & Demam timbul setelah nyeri perut \\
\hline G007 & Demam tinggi \\
\hline G008 & Nyeri perut bagian kanan bawah \\
\hline G009 & Rasa sakit meningkat 1 x 24 jam \\
\hline G010 & $\begin{array}{l}\text { Perut bagian kanan bawah terasa nyeri saat di tekan } \\
\text { dan di lepas }\end{array}$ \\
\hline & $\begin{array}{l}\text { Perut bagian kanan terasa bengkak dan tegang saat } \\
\text { di raba }\end{array}$ \\
\hline G011 & $\begin{array}{l}\text { Perut bagian kanan terasa nyeri saat kaki kanan di } \\
\text { tekuk menempel ke perut }\end{array}$ \\
\hline & Tabel 3:Gejala Radang Usus Buntu
\end{tabular}

Berikut ini adalah daftar gejala radang usus buntu kronis:

\begin{tabular}{cl}
\hline Kode Gejala & \multicolumn{1}{c}{ Gejala } \\
\hline G001 & Nyeri Ulu hati \\
\hline G002 & Mual dan Muntah \\
G003 & $\begin{array}{l}\text { Nyeri samar dibagian pusar berpindah ke kanan } \\
\text { bawah }\end{array}$ \\
\hline G004 & Nyeri perut bagian kanan yang hilang timbul \\
\hline G005 & $\begin{array}{l}\text { Sakit perut bagian kanan bawah lebih dari dua } \\
\text { minggu }\end{array}$ \\
\hline G006 & Demam timbul setelah nyeri perut \\
\hline G010 & $\begin{array}{l}\text { Perut bagian kanan bawah terasa nyeri saat ditekan } \\
\text { dan tekan lepas }\end{array}$ \\
\hline
\end{tabular}

Tabel 4:Gejala Radang Usus Buntu Kronis

Berikut ini adalah daftar gejala radang usus buntu akut: 


\begin{tabular}{cl}
\hline Kode Gejala & \multicolumn{1}{c}{ Gejala } \\
\hline G007 & Demam Tinggi \\
\hline G008 & Nyeri perut bagian kanan bawah \\
\hline G009 & Rasa nyeri meninggkat 1x24 jam \\
\hline G010 & $\begin{array}{l}\text { Perut bagian kanan bawah terasa bengkak dan tegang } \\
\text { saat di raba }\end{array}$ \\
\hline G011 & $\begin{array}{l}\text { Perut bagian kanan bawah terasa nyari disaat ditekan } \\
\text { dan tekan lepas }\end{array}$ \\
\hline G012 & $\begin{array}{l}\text { Perut bagian kanan terasa nyeri saat kaki kanan di } \\
\text { tekuk menempel ke perut }\end{array}$ \\
\hline \multicolumn{1}{c}{ Demam Tinggi } \\
\hline
\end{tabular}

\section{c. Data Relasi Penyakit dan Gejala}

Berikut ini adalah daftar relasi penyakit dengan gejalanya:

\begin{tabular}{|c|c|c|c|}
\hline & & PEI & \\
\hline \multirow{13}{*}{ G E J A L A } & KODE & $\mathbf{A}$ & B \\
\hline & G001 & & $*$ \\
\hline & G002 & & $*$ \\
\hline & G003 & & $*$ \\
\hline & G004 & & $*$ \\
\hline & G005 & & $*$ \\
\hline & G006 & & $*$ \\
\hline & G007 & $*$ & \\
\hline & G008 & $*$ & \\
\hline & G009 & $*$ & \\
\hline & G010 & $*$ & $*$ \\
\hline & G011 & $*$ & \\
\hline & G012 & $*$ & \\
\hline
\end{tabular}

Tabel 6:Relasi Penyakit dan Gejala

Keterangan:

Penyakit A :Radang usus buntu Akut

Penyakit B :Radang usus buntu Kronis

\section{d. Aturan Kaidah Produksi}

Berdasarkan tabel 6, dapat disimpulkan kaidah produksinya adalah:

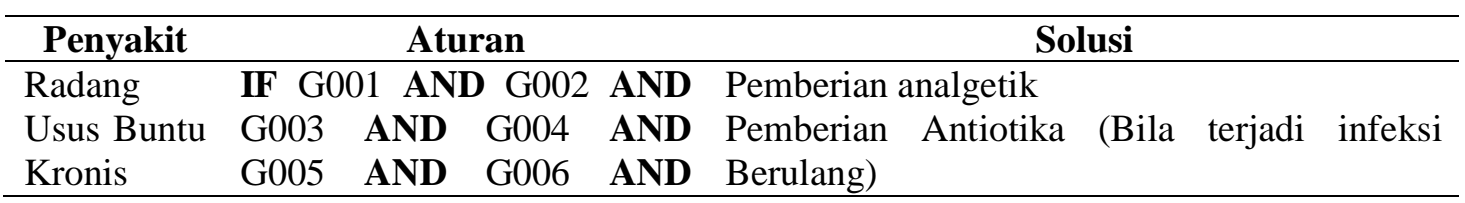




\begin{tabular}{|c|c|c|}
\hline & $\begin{array}{l}\text { G010 THEN Radang Usus } \\
\text { Buntu Kronis }\end{array}$ & $\begin{array}{l}\text { Pemberian Obat Penghilang Rasa Nyeri. } \\
\text { Operasi ( Apendektomi Elektif ) yaitu operasi } \\
\text { yang bisa di rencanakan atau di tunda. }\end{array}$ \\
\hline Radang & G007 & Pemberian analgetik \\
\hline Usus Buntu & ANDG009 AND G010 AND & Pemberian Antiotika (Bila terjadi infeksi \\
\hline Akut & G011 AND G012 THEN & Berulang) \\
\hline & Radang Usus Buntu Akut & Pemberian Obat Penghilang Rasa Nyeri. \\
\hline & & Antiperitik \\
\hline & & $\begin{array}{l}\text { Operasi ( Apendektomi Urgent) yaitu operasi } \\
\text { yang harus segela di laksanakan karna pada } \\
\text { jenis akut bisa menyebabkan Perporasi atau } \\
\text { pecah. }\end{array}$ \\
\hline
\end{tabular}

Tabel 7: Aturan Kaidah Produksi

\section{e. Analisa Proses}

Pada proses pencarian pada pohon pelacakan diatas,untuk menentukan status diagnosa maka akan di hitung dengan rumus proporsi yaitu menentukan kemungkinan frekuensi relatif.

Rumus proporsi pada sistem pakar untuk diagnosa penyakit radang usus buntu yaitu :

Keterangan :

P : Proporsi

$\mathrm{n}(\mathrm{A}) \quad$ : Banyak gejala yang terdeteksi pada penyakit A.

$\mathrm{n}(\mathrm{S}) \quad$ :Banyak gejala yang dimiliki penyakit A.

$$
\mathrm{p}=\frac{n(A)}{n(S)} \times 100 \%
$$

Setelah diketahui nilai proporsinya maka akan ditentukan status hasil diagnosa dengan aturan sebagai berikut :

1. Nilai Proporsi $=(100 \%)$ maka status hasil diagnosa adalah "Bisa dipastikan" .

2. Nilai Proporsi $=(>=56 \%$ AND $<100 \%)$ maka status hasil diagnosa adalah" Kemungkinan".

3. Nilai Proporsi $=(<56 \%)$ maka status hasil diagnosa adalah" Diragukan”.

\subsection{Hasil Sistem}

Pada tampilan awal sistem ini memberikan pengetahuan pertama mengenai usus bersih dan radang usus, sebagai salah satunya terlihat pada gambar 5 dibawah ini: 


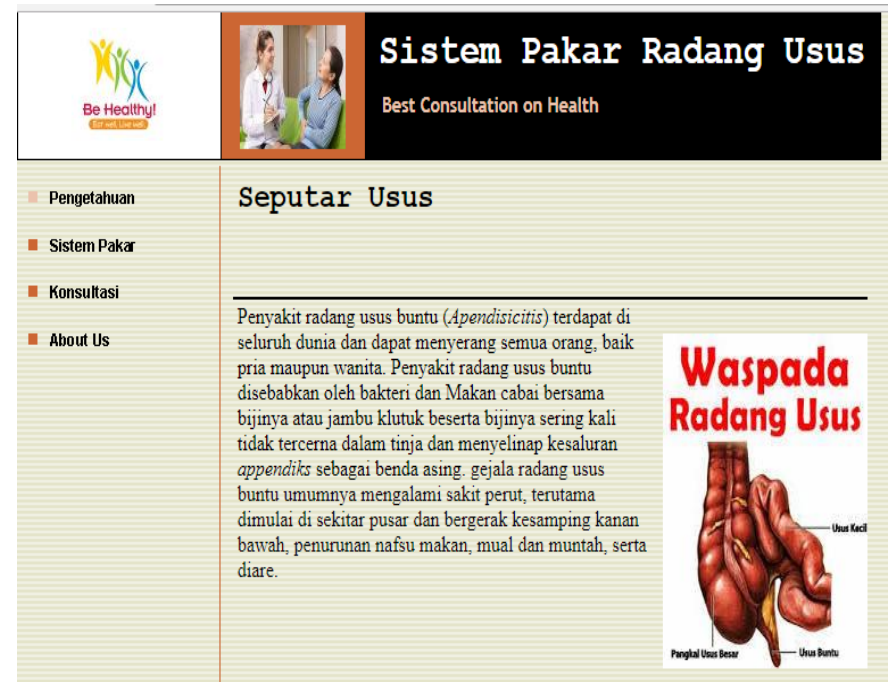

Gambar 5: Perancangan Tampilan Awal

Dalam sistem ini juga diberikan informasi cerdas mengenai pemahaman tentang sistem pakar dengan tujuan user memahami fungsi dari sistem yang dibuat. Dan tidak menyalahartikan fungsi dari sistem pakar sebenarnya, tampilannya seperti pada gambar 6 berikut.

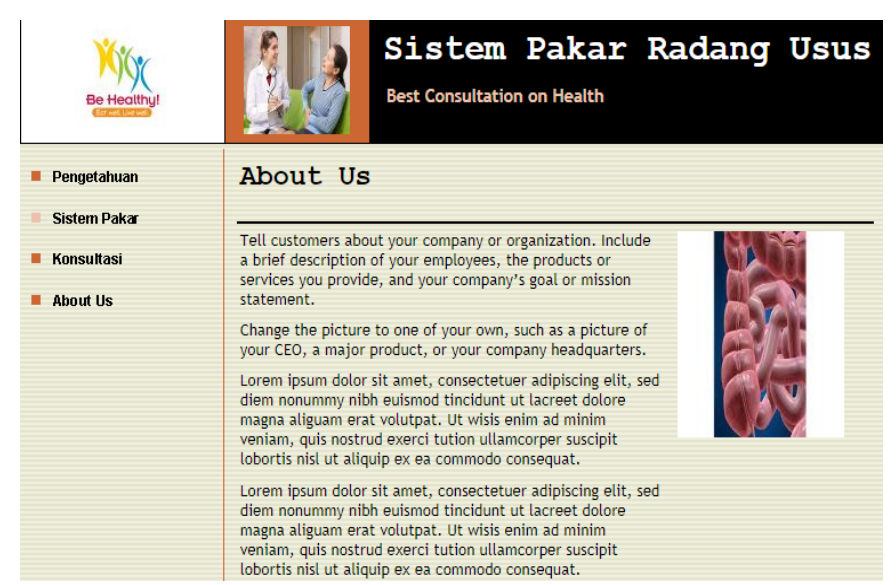

Gambar 6: Perancangan Tampilan Awal

Pada tampilan konsultasi ini menampilkan pertanyaanan user dapat menceklistnya sesuai dengan keluhan yang sedang di alami lalu klik periksa pada form "konsultasi" dan sistem akan menampilkan hasil diagnosa dan bisa dilihat pada gambar 7 berikut. 


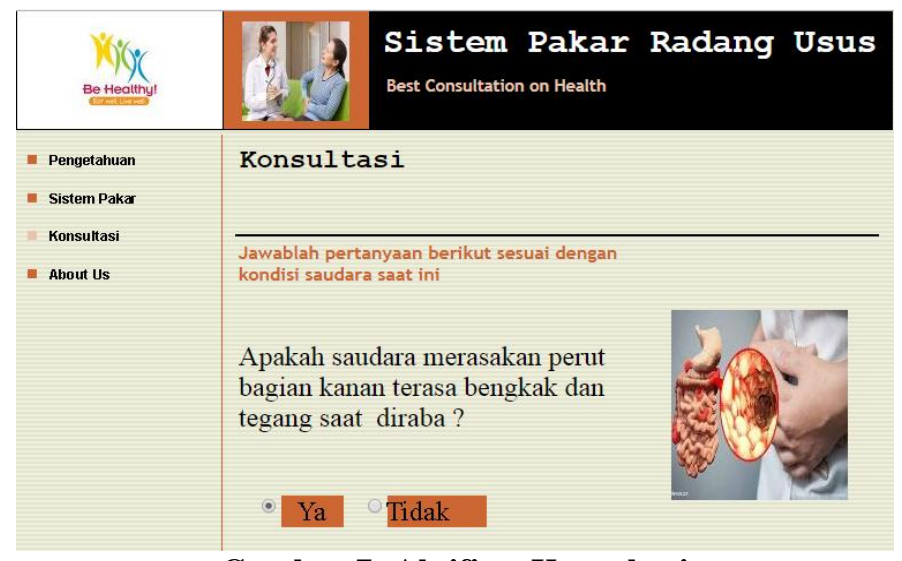

Gambar 7: Aktifitas Konsultasi

Dari aktifitas konsultasi diatas, dari beberapa pertanyaan yang akan membatu dalam pengambilan keputusan sebagaimana contoh pada gambar 8 berikut.

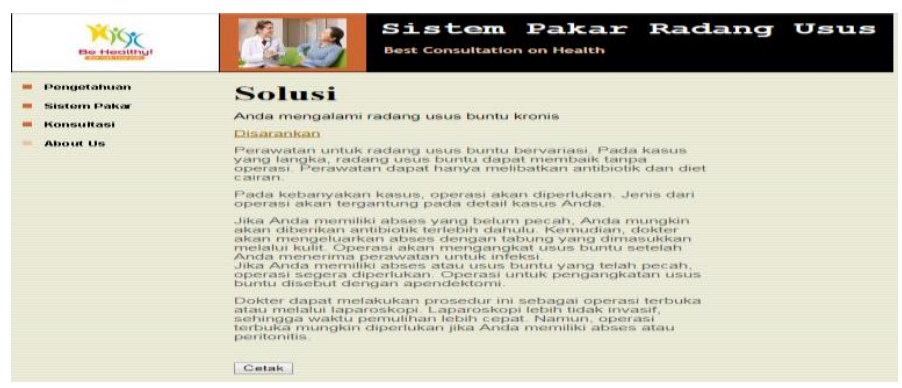

\section{Gambar 8: Solusi}

\section{Kesimpulan}

Berdasarkan analisis dan pembahasan yang dilakukan, maka dapat disimpulkan beberapa hal sebagai berikut :

1. Ada beberapa faktor yang dapat menentukan radang usus buntu. Faktor yang mempengaruhi tersebut diperoleh dari beberapa pilihan yang diberikan sistem, sehingga akan dihasilkan perencanaan sistem pakar untuk menentukan pasien mengalami radang usus

2. Sistem yang dirancang dapat menentukan kemungkinan radang usus pasien berdasarkan data pilihan user yang dimasukan.

3. Penalaran dilakukan dengan menggunakan metode backward Chaining dengan tujuan untuk memberikan persentase kemungkinan pasien mengalami radang usus.

4. Output dari sistem ini dalam bentuk informasi untuk membantu pasien radang usus atau perawatan bagi penderita radang usus dalam tahap awal yang dilihat dengan menggunakan sistem yang berbentuk hardcopy. 


\section{Referensi}

[1] A. Arifuddin, L. Salmawati, and A. Prasetyo, "Faktor Resiko Kejadian Apendisitis di Bagian Rawat Inap RSU Anutapura Palu 2017," J. Prev., vol. 8, no. 1, pp. 26-33, 2017.

[2] Firna Yenila, Yogi Wiyandra. 2016. "JURNAL TEKNOLOGI INFORMASI \& PENDIDIKAN VOL . 9 NO . 3 September 2016 ISSN : 2086 - 4981.” 9(3): 50-58.

[3] Kusumadewi, Sri (2003)."Artificial Intelligence (Teknik dan aplikasinya)". Graha Ilmu: Yogyakarta

[4] Suyanto (2011). “Kecerdasan Buatan". Andi: Yogyakarta

[5] Sutojo, dkk, 2011, Kecerdasan Buatan, Yogyakarta: Andi 